KYKLOS, Vol. 54 - 2001 - Fasc. 1, 3-26

\title{
Rational Ignorance versus Rational Irrationality
}

\author{
Bryan Caplan*
}

Brady: I do not think about things that... I do not think about!

Drummond: Do you ever think about things that you do think about?

Jerome Lawrence and Robert E. Lee, Inherit the Wind (1982, p. 97)

\section{INTRODUCTION}

Scarcity of information increases the expected absolute magnitude of your mistakes, but does not bias your estimates or prompt you to treat noise as if it were knowledge. An important implication is that even rational ignorance is consistent with rational expectations (Pesaran 1987, Sheffrin 1996). Voters' minimal purchase of political information, for example, makes large mistakes likely, but not systematically biased mistakes (Becker 1976a, Coate and Morris 1995, Wittman 1995, 1989). There is also no reason for a rationally ignorant individual to be dogmatic; he sees that his opinion could easily be wrong due to lack of information.

Downs (1957) introduced the theory of rational ignorance to explain why voters know so little about seemingly important issues: when the expected benefits of information are small (as they almost always will be in an election), people buy little information. Much subsequent economic analysis of politics builds on the assumption that 'Downsian' incentives foster rational ignorance (Olson 1982, 1965, Magee, Brock, and Young 1989). Religious believers' low level of knowledge about their own (and other) religions could also be seen as

* Assistant Professor, Department of Economics and Center for Study of Public Choice, George Mason University, Fairfax, VA 22030. E-Mail: bcaplan@gmu. edu; phone: 703-993-2324. For discussion and useful suggestions I would like to thank Don Boudreaux, Tyler Cowen, Pete Boettke, Jim Schneider, Geoffrey Brennan, Bill Dougan, Bill Dickens, Mitch Mitchell, Ed Lopez, J. C. Bradbury, Todd Zywicki, David Bernstein, Corina Caplan, Robin Hanson, Dan Klein, Alex Tabarrok, Nicky Tynan, Timur Kuran, René Frey, two anonymous referees, seminar participants at George Mason, participants at the Public Choice Outreach seminar, and members of my Armchair Economists' listserv. Gisele Silva and Scott Beaulier provided excellent research assistance. The standard disclaimer applies. 
instances of rational ignorance. But one puzzling feature of many people's political and religious beliefs is that they invest little effort in gathering information, but still hold them with certitude or near certitude (Frey 1997, Hardin 1997). Nearly two-thirds (64.4\%) of respondents to the General Social Survey (1996) have 'no doubts' about the existence of God, and more than two-thirds $(68.4 \%)$ say that conflicts between faith and science have 'never' caused them to doubt their faith ${ }^{1}$. Hoffer (1951) points out that political movements often call forth the same degree of certitude.

What compounds the puzzle is that many of these beliefs - political or religious - are systematically mistaken. During the Middle Ages, people who overestimated the probability that witches exist were not balanced out by equal numbers who underestimated this probability. Similarly, socialist revolutionaries have repeatedly expected forced collectivization to dramatically improve agricultural productivity, even though such experiments have been uniformly disastrous (Conquest 1985, Becker 1996). To treat these as unexceptional instances of rational ignorance strains credulity.

What follows is an alternative model of 'rational irrationality', that explains why people hold systematically biased, low-information, high certitude beliefs; in other words, why they deviate from the rational expectations assumption (Caplan 2000a). In the model, agents trade off utility from beliefs against utility from states of affairs (Akerlof and Dickens 1982, Akerlof 1989). If the most pleasant belief for an individual differs from the belief dictated by rational expectations, agents implicitly weigh the hedonic benefits of deviating from rational expectations against the expected material costs of self-delusion. Combining the model with the Downs/Olson insight that some kinds of errors are privately costless provides an intuitive framework for judging when beliefs are likely to be 'irrational'.

The next Section provides background on ignorance and irrationality. The third presents the model and contrasts it with other theoretical accounts of apparently irrational belief. Section four applies the model to political opinion, religious belief, science and pseudo-science, and jury decisions. Section five contrasts cases where private irrationality is optimal to situations where it produces socially inefficient results. Section six concludes the paper.

1. Henceforth GSS. Author's tabulation, variable identifiers GOD and DOUBTS3. Note that the GSS is based on interviews with U.S. respondents. 


\section{IGNORANCE AND IRRATIONALITY: BACKGROUND}

\section{The Limits of Ignorance}

Wittman $(1995,1989)$ vigorously advances the claim that economists often mistakenly move from rational ignorance to systematic bias on an ad hoc basis. Voters' rational ignorance is a poor explanation for, e.g., inefficient Congressional spending patterns:

'To be uninformed about the nature of pork-barrel projects in other congressional districts does not mean that voters tend to underestimate the effects of pork barrel - it is quite possible that the uninformed exaggerate both the extent and the negative consequences of pork-barrel projects' $\left(1995\right.$, pp. 15-16) ${ }^{2}$.

Even if politicians or special interests lie or 'obsfucate' their intentions (Magee, Brock, and Young 1989), the worst this can do to rational voters in equilibrium is merely increase the variance, not the mean value, of their estimates of programs' net benefits.

What the approach of Wittman and others overlooks, however, is the possibility that agents optimize over two cognitive margins: the quantity of information they acquire, and how rationally they process the information they do have (see Figure 1; Frey and Eichenberger 1994). The quality of an agent's estimate depends on both. This is critical because the theoretical justifications for rational expectations typically presume that irrationality has private costs (Muth 1961). Thus, the key assumption underlying rational ignorance - minimal private benefit of information - negates the standard case for rational expectations. This suggests that economists have been too quick to invoke rational ignorance: the incentives that foster non-committal ignorance could just as easily give rise to irrational conviction.

2. Moreover, Wittman notes, the rational response of the relatively ignorant to asymmetric information is to buy less, not more of a product: hence, if politicians know more about programs than rationally ignorant voters, this leads citizens to keep government budgets lower, not higher, than they would with symmetric information (1995, pp. 107-108). Nor do voters need much information to adequately deter opportunism: As the theory of optimal punishment emphasizes, one can compensate for the improbability of detection with more severe sanctions. And since politicians are typically relatively wealthy, severe punishments could be imposed without large deadweight costs (Becker 1968, Bender and Lott 1996). 
Figure 1

Incentives and Estimation

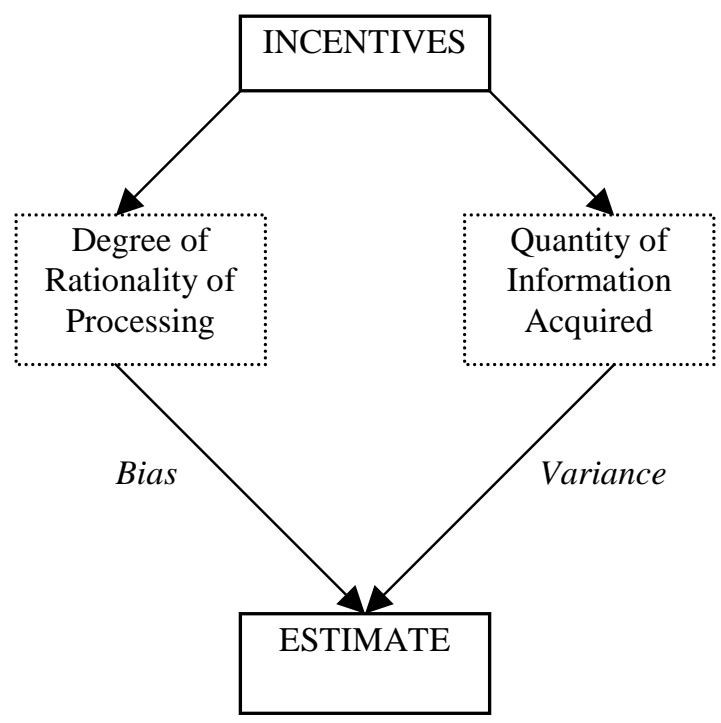

\section{Earlier Treatments of Irrationality}

A number of economists have admitted the existence of irrationality, distinct from ignorance, but with one important exception (Akerlof and Dickens 1982), they treat irrationality as an exception to - rather than an application of - basic microeconomic theory. Many of these claim that irrationality is particularly pronounced in politics (e.g., Schumpeter 1976), but again with one exception (Akerlof 1989), they do not have a theoretical explanation for this pattern. Voter rationality is the main theme of Becker's work on the economics of politics (e.g., 1976a), but at times he claims almost the opposite. For example, 'A Theory of Competition Among Pressure Groups for Political Influence' states:

'I too claim to have presented a theory of rational political behavior, yet have hardly mentioned voting. This neglect is not accidental because I believe that voter preferences are frequently not a crucial independent force in political behavior. These 'preferences' can be manipulated and created through the information and misinformation provided by interested pressure groups, who 
raise their political influence partly by changing the revealed 'preferences' of enough voters and politicians' (Becker 1983, p. 392).

Pressure groups use their wealth to put out 'misinformation', voters hear it, and proceed to move their average beliefs closer to the ones the pressure group wants them to have. Normally, this would be a sign of irrationality. What is it that makes political beliefs special? Becker does not explain.

The psychology and economics literature (Camerer 1995, Rabin 1998, Caplan 2000a) also frequently argues that beliefs are irrational in some respect. People misunderstand the law of large numbers, misinterpret evidence, and tend to misread new information as confirmation of their previous beliefs. The psychological anomalies that appear in market-type settings have been studied most intensively; Quattrone and Tversky (1988) extend the approach to political beliefs, but do not argue that deviations from rationality are particularly likely to stand out in this realm. Other pieces that introduce psychological anomalies to the economics of politics include Frey and Eichenberger (1991), Kirchgässner and Pommerehne (1993), Kuran and Sunstein (1999), and Blais and Young (1999).

Probably the first economic theory of irrationality appears in Akerlof and Dickens (1982). The key result is that agents start with rational expectations about the underlying trade-offs, but choose some degree of self-delusion. Akerlof and Dickens mainly apply their model to standard market behavior, such as optimal safety decisions; they do not use it to analyze voting - except to argue that the presence of cognitive dissonance in markets helps explain why citizens vote for government policies to counter-act it (Akerlof and Dickens 1984, pp. 141, 143). However, Akerlof (1989) does extend the analysis to political belief, combining choice over beliefs with the Downsian incentives.

\section{RATIONAL IRRATIONALITY}

\section{The Model}

Suppose that an individual has well-defined preferences over states of affairs and beliefs about the world. These preferences can be represented with indifference curves (Caplan 2000a), which in turn imply the individual's 'demand for irrationality' curve (see Figure 2). 'Quantity' of irrationality - i.e., degree of deviation from rational expectations - appears on the $\mathrm{x}$-axis, while the 'price' of irrationality appears on the y-axis. 
The price line shows how much material wealth one sacrifices for a given quantity of irrationality ${ }^{3}$. The critical assumption - which makes this a model of rational irrationality rather than 'irrational irrationality' - is that the agent perceives the price line without bias. On some level, the agent has rational estimates of the attendant consequences of self-deception. Overestimating your ability to work while intoxicated exposes you to the risk of firing or lawsuits, and underestimating the efficacy of modern medicine compared to faith-healing forces you to forego potentially life-saving medical treatments. Material wealth is greatest when the agent has rational expectations (i.e., quantity of irrationality is zero), but agents with a taste for irrationality are likely to trade off some material wealth in exchange for more satisfying beliefs.

Figure 2

Individual Demand for Irrationality

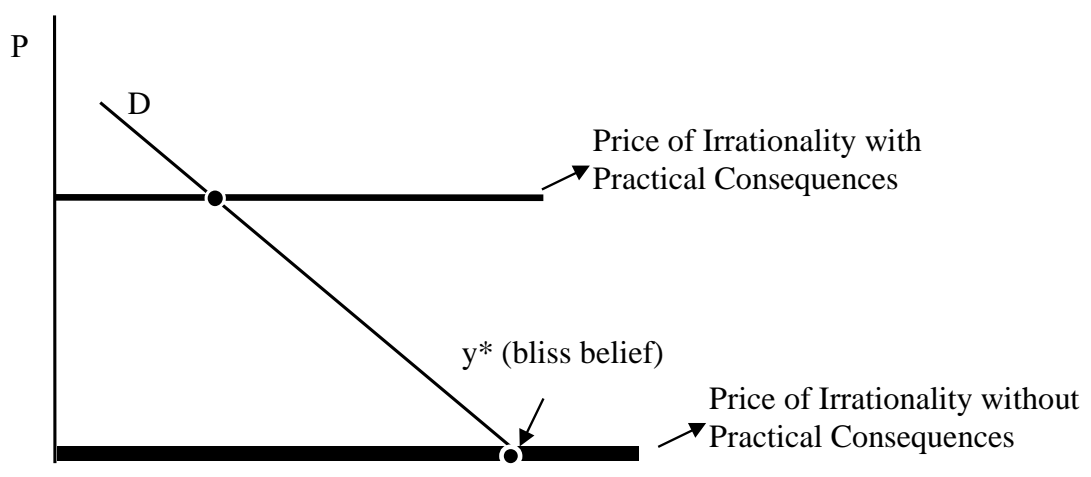

Quantity of Irrationality

The model's last assumption is that agents have a 'bliss belief' - graphically, the point where their demand curve crosses the $\mathrm{x}$-axis (see Figure 2). The idea is that agents deviate from rational expectations because they have a specific alternate belief that they like to think is true, not because they want to be as far from the truth as possible ${ }^{4}$. For example, a fundamentalist's bliss belief might

3. For convenience, it is assumed that losses are linear and symmetric around the unbiased belief, implying a flat price line, but in principle this need not be the case.

4. The price of irrationality would have to be negative to induce an agent to accept a belief more irrational than his bliss belief. Caplan (2000a) discusses special cases where this might occur. 
be that the earth is 6000 years old; it pains him to believe that the earth's age is either more or less.

As with consumer theory generally, one should not read too much psychological content into this model. There is no need to imagine agents explicitly thinking 'How much will I pay to persist in my delusions?'. Introspectively, it is more plausible to think of agents adjusting their level of intellectual self-discipline and emotionalism to match the practical import of the questions they face.

A key feature of beliefs is that some have practical consequences for the individual adherent, while others do not (Kliemt 1986, Kirchgässner 1992, Kirchgässner and Pommerehne 1993). The belief that protectionism is a wealth-enhancing national policy does not prevent the individual adherent from enjoying the benefits of international trade. In contrast, holding that household self-sufficiency is the path to prosperity has large private costs. One's belief about the relative merits of evolution and creationism is unlikely to make a difference to one's career outside of the life sciences, but maintaining that faith-healing is more effective than modern medical science may be deadly. As with other decisions, it is important to focus on marginal incentives. 'What if everyone thought that way?' is not the relevant question for an individual actor. The real question is rather: 'What would be different if I changed my mind?'. If the answer is 'nothing', there is no marginal incentive to analyze the problem in an unbiased way. Note further that there are two ways for the 'nothing' answer to play out. The first is that the individual's belief has no practical implications for anyone; for example, belief in transubstantiation. The second is that the total practical implications are privately inconsequential but socially significant. One more protectionist voter may have a trivial impact on policy, but as in other collective action situations, a trivial impact experienced by millions of people adds up.

The two price lines in Figure 2 illustrate the contrast between privately costly and privately costless irrationality. When beliefs have practical consequences, there is a positive price of irrationality; the milder the consequences, the lower the price. In contrast, when there are no practical consequences, the price line overlaps with the $\mathrm{x}$-axis. In this case, the agent always chooses his 'bliss' belief.

The theory of rational irrationality, like the theory of rational ignorance, predicts that when private error costs are zero, agents will gather little information. But unlike the rationally ignorant, the rationally irrational nevertheless form definite conclusions. They know what they want the truth to be, and if error is cheap, they choose their 'bliss' belief even if they have little information to go on. When private error costs are zero, conclusions that are at the same time baseless and unreasonable should be expected.

The puzzle this model aims to explain is low information, systematically biased, excessively certain beliefs. It might seem that this model can only explain 
the first two properties, providing no insight into excessive certainty. But let an agent's estimate of the accuracy of his estimates be another belief that the agent chooses over. Then along this dimension as well, an agent can trade off wealth for irrationality. As the price of overestimating the accuracy of one's estimates falls, certainty becomes a psychological good even the uninformed can afford. It seems likely that systematic bias about a belief and systematic bias about the belief's certitude are complements: it is not too pleasant to affirm unreasonable views with a healthy dose of skepticism. As John Locke puts it,

'These, of all men, hold their opinions with the greatest stiffness; those being generally the most fierce and firm in their tenets, who have least examined them' (1951, p. 371).

My model differs from the one presented in Akerlof and Dickens (1982) in two important respects: one formal, one informal. The main formal difference is that mine does not assume that beliefs are fixed after their initial selection. Rather, the belief one chooses stays sensitive to relative price changes; when a belief suddenly becomes more costly to hold, people often recant. An example from Gaetano Mosca provides a good illustration:

\footnotetext{
'Mohammed, for instance, promises paradise to all who fall in a holy war. Now if every believer were to guide his conduct by that assurance in the Koran, every time a Mohammedan army found itself faced by unbelievers it ought either to conquer or to fall to the last man. It cannot be denied that a certain number of individuals do live up to the letter of the Prophet's word, but as between defeat and death followed by eternal bliss, the majority of Mohammedans normally elect defeat' (1939, pp. 181-182).
}

It is difficult to think that the warriors were faking their devotion to Islam all along, yet standard rational expectations models of belief formation are unable to explain such sudden changes of opinion. By imposing the assumption of belief fixity, Akerlof and Dickens artificially hobble their model's ability to generate the explanation: Beliefs respond to price changes (Frey and Eichenberger 1994). On some level, adherents remain aware of the price they pay for their beliefs. Under normal circumstances, the belief that death in holy war carries large rewards is harmless, so people readily accept the doctrine. But in extremis, as the tide of battle turns against them, the price of retaining this improbable belief suddenly becomes enormous. Widespread apostacy is the result; believers flee the battlefield in disregard of the incentive structure they recently affirmed ${ }^{5}$.

5. A small percentage, as Mosca points out, will choose to give their lives for their beliefs. The point is merely that the average price-elasticity of beliefs is significant, not that it is significant for everyone. 
One might be inclined to interpret Mosca's example as hypocrisy in a prisoners' dilemma: the warriors believe they ought to stand firm, but in their own self-interest they flee. But the point is that if their initial beliefs were true, it would be maximally in their interest to die fighting and win eternal bliss; the soldier who keeps his original belief and perishes pursues his perceived selfinterest no less than the compatriot who changes his original belief and flees. What the dire circumstances seem to shock is rather the perception itself: when the price rises, adherence to unwarranted beliefs becomes a superfluous luxury. The soldiers adjust their optimal wealth/irrationality bundles, which in turn realigns where they think their self-interest lies.

The main informal difference between the current model and Akerlof and Dickens (1982) and Akerlof (1989) is that I give no specific psychological, anthropological, or sociological interpretation to choice over beliefs. Nor do I assume, as, e.g., Kuran (1995a) does, that choice over beliefs is necessarily a gradual process. Rather I interpret it in the very general terms that Locke characterizes as 'enthusiasm':

\footnotetext{
'For the evidence that any proposition is true (except such as are self-evident) lying only in the proofs a man has of it, whatsoever degrees of assent he affords it beyond the degrees of that evidence, it is plain that all the surplusage of assurance is owing to some other affection, and not to the love of truth' (1951, p. 429; emphasis added).
}

The 'other affections' which give rise to the 'surplusage of assurance' are nothing out of the ordinary: Locke mentions 'conceit', 'laziness, ignorance, and vanity', and 'the tedious and not always successful labor of strict reasoning'.

Becker maintains that the ultimate arguments of stable utility functions should not be market goods and services, but rather fundamental aspects of life, such as 'envy, prestige, physical and psychological health'. He approvingly cites Bentham's list of fifteen 'simple pleasures' including 'piety', 'imagination', and 'hope' (1976c, pp. 137, 147-148). The motivations Locke explores fit comfortably into this Beckerian framework. The 'economic approach to human behavior' need not discount evidence from specific psychological, anthropological, or sociological theories (Ackerlof, 1989, Rabin 1998), but it analyzes choice over beliefs without appealing to them.

\section{Is Irrationality an Illusion?}

Four disparate lines of research raise the possibility that the irrationality of political and/or religious beliefs may be merely apparent. There is Kuran's (1995a) theory of preference falsification; Fremling and Lott's (1989, 1996) 
analysis of the 'bias toward zero in aggregate perceptions'; Brennan and Lomasky's $(1989,1993)$ work on expressive voting; and Iannaccone's (1992) model of religion as a club good.

Preference falsification. Kuran (1995a) emphasizes that people often falsify their preferences. They affirm beliefs not because they actually hold them, but because they find it safer to pledge allegiance to officially palatable views. When uninformed people dogmatically publicize a systematically biased estimate, many are concealing their true beliefs - or their rational ignorance.

Pushing Kuran's analysis to its extreme limits (though he does not), it could be argued that all apparent irrationality amounts to preference falsification. But if no one actually believes the official opinion, it is difficult to see why people promulgate it or sanction critics ${ }^{6}$. Kuran's work and mine can however be viewed as broadly complementary: He explains how a minority of adherents can pressure others into pretending to share their view, while my model shows why there are any irrational adherents to begin with.

Bias toward zero in aggregate perceptions. Since the number of possible ways the economy works is enormous, Fremling and Lott $(1989,1996)$ argue that people implicitly estimate only a handful of econometric models to conserve mental resources. Agents' estimates are unbiased if their model is correct. However, if they misspecify the model, that sets their coefficient estimate for the omitted variables to zero. Unless everyone includes a variable in their model, the absolute value of the average coefficient will be too small. For example, Fremling and Lott note that during the 70's, polls showed that few people even considered the possibility that price controls were the cause of shortages, biasing the average estimate to zero.

'Thus, we are relying not on voter 'stupidity' or 'irrationality', but solely on differential costs of information' (Fremling and Lott 1989, p. 295).

While Fremling and Lott provide a plausible account of some apparent irrationality, its applicability is limited. Consider their observation that most people blamed domestic oil companies or OPEC rather than price controls for gas shortages. How would randomly selected members of the public have reacted if an economist suggested adding a price control variable to their specification? Some, pace Fremling and Lott, would say 'I hadn't thought of that', and change their minds. Others, however, would probably respond with hostility rather than

6. One possibility is that rebellion is a coordination game; by creating an official orthodoxy, the government makes it more difficult for dissidents to use 'cheap talk' to move to the rebellious equilibrium. Still, it is unclear why it is necessary to make everyone pretend that they are delighted with the government, rather than merely too frightened to contemplate resistance. 
curiosity, in spite of their cursory study of economics (Caplan 2000 b). It is the belief formation process of the latter group that my model tries to account for. Expressive voting. Since a voter's choice is almost never decisive, Brennan and Lomasky $(1989,1993)$ argue 'expressive' not 'instrumental' values determine how (not just whether) people vote. This can lead to what Brennan and Lomasky call 'the voters' dilemma': if everyone indulges their expressive tastes, ignoring the actual consequences of policies, emotionally appealing but suboptimal policies win out.

Brennan-Lomasky challenges the collective rationality of democratic decision-making, and thereby indirectly affirms voters' individual rationality. A person can have rational expectations about the effects of different policies, but still vote for those with the most emotional appeal. Still, how much expressive value can voting for counter-productive policies have? If people had rational expectations about the consequences of gas price controls, would it still be inspiring to vote for them? Instrumental beliefs frequently seem to underlie expressive preferences. If these instrumental beliefs were rational, then the collectively irrational effects of expressive voting would probably be mild.

Religion as a club good. Iannaccone (1992) proposes a rational choice explanation for 'subjective belief, forced indoctrination, and outright irrationality' (1992, pp. 271-272) and related forms of religious behavior. He points out that religion is a club good with special free-rider problems:

'The aspects of religious participation that confer external benefits (commitment, effort, enthusiasm, etc.) are intrinsically difficult to monitor' (1992, p. 274).

Religions respond by 'taxing' secular substitutes. For example, they may forbid eating pork, or insist that members live in an isolated commune.

Still, there is more to religions than activities; there is also a set of beliefs that adherents are supposed to - and frequently do - sincerely embrace ${ }^{7}$. Sometimes these beliefs are, like creationism, highly improbable. Yet despite limited exposure to the evidence, religious adherents tend to hold their doctrines with virtual certainty. Iannaccone's extension of his model to fraternal hazing, tribal disfigurement, and other 'clubs' with no doctrinal component is revealing. What the theory of rational irrationality adds to his analysis is an explanation for dogmatic, systematically biased beliefs resting on little or no information.

7. Iannaccone (1998, pp. 1490-1491) agrees that the economic approach to religion has not yet adequately analyzed religious belief formation or distinguished religious from social clubs. 


\section{RATIONAL IRRATIONALITY: APPLICATIONS}

This Section offers examples where systematically biased beliefs are common and the private costs of error are low. It separately examines political beliefs, religious beliefs, science and pseudo-science, and juries, argues that in these areas the private costs of error are usually negligible, and presents evidence that irrationality is inordinately pronounced in each of the four ${ }^{8}$.

\section{Political Beliefs}

Just as it is unlikely that one vote will change an election, it is improbable that one's person's political beliefs will change society. For most individuals the private cost of choosing one political ideology over another is about zero ${ }^{9}$ (Brennan and Lomasky 1993, Eichenberger and Oberholzer-Gee 1998). While science cannot resolve disputes about normative rankings, it can provide a benchmark against which to judge the rationality of any descriptive claims ideologies put forward (Nisbett and Ross 1980).

Probably the clearest examples of irrational political beliefs come from totalitarian movements such as Communism and Nazism - an irrationality that most commentators see as a central feature of these regimes (Hoffer 1951, Friedrich and Brzezinski 1965, Arendt 1973, Orwell 1983). Orwell famously termed totalitarian irrationality 'doublethink':

'Doublethink means the power of holding two contradictory beliefs in one's mind simultaneously, and accepting both of them' (1983, p. 176).

Admittedly, many subjects of totalitarian regimes uphold the party line out of fear rather than devotion (Kuran 1995a, Wintrobe 1998), but every ideology has its share of sincere fanatics. 'True believers' are easiest to single out during

8. One prefatory note: Haltiwanger and Waldman (1989) distinguish the strict version of the rational expectations hypothesis, according to which every individual has rational expectations, from 'rational expectations in the aggregate' according to which all individuals' systematic biases cancel out. If every individual has rational expectations, then rational expectations in the aggregate necessarily holds. The converse is not true: rational expectations in the aggregate may hold even if many people have systematic biases. But the contrapositive, as always, is true: If rational expectations in the aggregate does not obtain, then it immediately follows that some individuals do not have rational expectations.

9. It is true that expressing some political beliefs carries a large stigma: publicly denying the reality of the Holocaust could cost a person his job. But it is the expression of the belief that carries the price; as Kuran (1995) emphasizes, preference falsification rather than belief alteration is the most common strategic response. 
a movement's infancy, but victory does not eliminate them (Mosca 1939, esp. pp. 163-198, Hoffer 1951).

The evidence of irrationality outside of totalitarian movements is less dramatic but still illuminating. Important political beliefs fail to satisfy rational expectations in the aggregate. One particularly universal pattern is 'ethnocentric' or anti-foreign bias (Reynolds, Falger, and Fine 1987). Tönnesmann argues that this is virtually a universal pattern in human societies, though the intensity varies:

\footnotetext{
'We attribute better characteristics to our own group than it really deserves, while the other groups get grades that are worse than they in fact deserve. Unfortunately, it seems to be true that it serves our own well-being when members of other groups are judged in terms that are worse than they would deserve on the basis of facts... This tendency to form prejudices appears to be biological in origin and remains pervasive, and it seems difficult to diminish because of the positively experienced consequences for our group feeling' (1987, p. 197).
}

Such ethnocentrism definitely seems pronounced in normative judgments. In the United States, usually perceived as relatively friendly towards free trade and open immigration, 'pro-foreign' policies are unpopular. Only $6.3 \%$ of Americans surveyed in the GSS favor increasing immigration by any amount, and fully $65.4 \%$ favor decreasing it; similarly, $74.2 \%$ hold that too much is spent on foreign aid ${ }^{10}$. But what is interesting from the point of view of this paper are the descriptive beliefs that underlie their normative views. The Survey of Americans and Economists on the Economy (1996) asked the general public and professional economists to assess various explanations for 'why the economy is not doing better than it is', as 'major reasons', 'minor reasons', or 'not a reason'. The American public was overwhelmingly more likely than randomly sampled members of the American Economic Association to see excessive foreign aid spending, immigrants, and jobs going overseas as 'major' problems ${ }^{11}$. In others words, the American public does more than just assign low weight to foreigners in the social welfare function; its also thinks, as a descriptive matter, that foreign aid, immigration, and foreign competition are quantitatively important problems.

While data of comparable quality for other nations is difficult to obtain, there is little reason to think that anti-foreign bias is especially pronounced in the United States. Nationalistic opposition to NAFTA also appeared in Mexico (Grinspun and Cameron 1993). Public opinion in France, Austria, and Ger-

10. Author's tabulation of the GSS (1996). Variable identifiers LETIN and NATAID.

11. Caplan (2000b) shows that enormous systematic belief differences between economists and the general public that appear in the Survey of Americans and Economists on the Economy persist controlling for diverse measures of self-serving and ideological bias. 
many (especially the eastern states) seems to assign unrealistically large shares of responsibility for economic woes to immigrants (Baumgarten and Favell 1995, Watts 1997). Historian Stanley Payne notes that during the rise of Nazism, Jews comprised less than $1 \%$ of the German population; but many nevertheless saw them as the primary cause of Germany's economic troubles (1995, p. 56).

A natural if uncharitable interpretation of national opinion about these issues is that foreigners (and out-groups more generally) make emotionally appealing scapegoats for economic problems. As Hoffer observes,

'The ideal devil is a foreigner' (1951, p. 87).

But this is not an irreducible 'taste for discrimination'. It derives from the firm belief that foreigners are really responsible for the economy's problems. Convincing yourself that immigrant taxi drivers are all 'dishonest foreigners' might have the same emotional appeal as thinking them responsible for economic troubles, but the former mistake is much pricier (at least in areas where people use taxis).

\section{Religious Beliefs}

While modern religions are much less likely to make specific, verifiable claims than they once were, some still do. Numerous religions reject the theory of evolution, and a smaller but substantial number still hold that the earth is a few thousand years old. $33.5 \%$ of GSS respondents affirm the literal truth of the entirety of the Bible, and over half say that the theory of evolution is either 'probably not true' $(16.4 \%)$ or 'definitely not true' $(35.3 \%)^{12}$. The high level of certainty is particularly interesting from the point of view of rational irrationality: note that the 'definite' disbelievers outnumber the 'probable' by a factor of more than 2:1. Again, the low private cost of disbelief is crucial. However, divorced from reality one is on these points, personal wealth is approximately unchanged - except for biologists and geologists.

The theory of rational irrationality can be easily applied to religious beliefs that conflict with known scientific evidence. But some such as Montgomery (1996) would probably limit its broader application, arguing that probability theory is not an adequate tool to cope with religious choices. 
'Religion involves not merely the unknown but the unknowable... Because the economic approach does assume that probabilities are knowable, I think it is fair to challenge economists to identify those signals that convey information about ultimate reality' (p. 445).

While this is a challenging question, it is not necessary for economists to answer it in order to apply the theory of rational irrationality to most religious belief. Suppose for the sake of argument that the reader's religious views are correct and justifiable. Now what can be said about the remaining $(\mathrm{N}-1)$ religious viewpoints in the world? If the adherents of the other (N-1) views had merely acquired little information compared to oneself, then their errors should be unbiased and their opinions tentative. From virtually any religious viewpoint, however, this does not seem to be the case: the Catholic for example must admit that Muslims, Jews, Hindus, atheists, and many other groups systematically underestimate the probability that Jesus was the Son of God - and their errors are not in any sense balanced out by other people who overestimate this probability. And while some people tentatively disagree because they have not seen the Church's evidence that Jesus was the Son of God, many others firmly disagree in spite of their low level of information. In sum, one need not be a religious skeptic to think that my model explains most religious belief ${ }^{13}$.

\section{Science and Pseudo-Science}

The practical success of science has not driven superstition into bankruptcy (Randi 1989). 52.5\% of respondents to the GSS maintain that astrology has 'some scientific truth' ${ }^{14}$. As Sagan observes,

'Each field of science has its own complement of pseudoscience... Botanists have plants whose passionate emotional lives can be monitored with lie detectors, anthropologists have surviving ape-men, zoologists have extant dinosaurs, and evolutionary biologists have Biblical literalists snapping at their flanks' (1995, p. 43).

Why does anyone turn to the pseudosciences for answers? The model of rational irrationality helps explain why: People have mixed cognitive motives. They want to find out the truth, but they also have pet theories that they want to be true. It is easier to tell a good story when unconstrained by the facts. Pseu-

13. Admittedly, if unbelievers were in reality certain to face dire divine punishments, then in my model it would not be appropriate to invoke a vertical or near-vertical budget line. But the propensity of many (e.g., the Muslim soldiers described in Mosca's previous quote) to act contrary to their own beliefs when the cost suddenly rises suggests that on some level they too believe that in reality the budget line is relatively steep.

14. Author's tabulation of the GSS (1996). Variable identifier SCITEST3. 
doscientists are trying to make people feel better rather than tell them possibly uncomfortable truths.

So long as the price of irrationality is low for both suppliers and demanders of pseudoscience, superstition can persist indefinitely. Pseudoscientists prosper as long as they feed clients' emotional needs without appreciable side effects on their wealth. This explains why most pseudoscientific 'forecasts' (astrology, psychic advisors, palm reading, etc.) are so vague that believers can still take the optimal action whatever it turns out to be. For example, Kuran (1995b) explains that 'Islamic economics' prohibits the charging of interest for a number of reasons that most economists would find difficult to take seriously. But especially in countries where 'Islamic banks' compete alongside traditional banks, there is a strong tendency to simply relabel interest as a 'profit share', even if it matches the fixed rate of interest available elsewhere. Patrons of Islamic banks enjoy the satisfaction of consistency with the Quran, without actually suffering from the misallocation of risk a genuine ban on interest would entail. Pseudoscience also unsurprisingly appeals to many people once conventional science can do nothing more for their problems.

Scientists and their clients face almost the opposite incentive structure: the price of irrationality becomes quite high. The primary reason is that scientists usually sell practical results that only someone tuned into the real world can produce. If a scientist disregards unpleasant evidence or scientific principles, his customers have the incentive to go elsewhere to get the practical results they want. The two groups mutually reinforce each other's commitment to look at the world rationally.

Scientific norms reinforce the incentive structure that gives science its almost unique reputation as a source of unbiased information. The scientific ethos is an implicit tax on dogmatic attitudes ${ }^{15}$. Its underlying rationale appears to be that even scientists will demand a positive quantity of irrationality if the price is low enough. The implicit tax the scientific community imposes on irrationality is - crucially - a private cost, prompting scientists to suppress their systematic biases. Scientific reputation may be a minor incentive for most, but it is almost the only constraint on theoretical physicists, evolutionary biologists, and others with few practical results to sell.

15. Cowen (1998) notes that norms can be self-enforcing so long as actors can produce genuine (non-strategic) esteem at zero cost. Science is special not because it punishes people for violating its norms, but because it upholds the norm of unprejudiced, rational search for truth. Other disciplines - astrology, for example - have norms against asking skeptical questions and demanding objective evidence. 


\section{Juries}

A juror's vote in a trial, unlike a citizen's vote in an election, often has a high probability of being decisive; in a criminal trial, one 'no' vote suffices to hang the jury. But it is the overall legal climate - not the outcome of one case - that affects a juror's wealth; and as a rule the outcome of one case has no appreciable impact on the overall legal climate. A juror's private cost of irrationality is therefore as trivial as the voter's; the juror's personal wealth will not vary no matter how ill-founded his opinion is (Tullock 1980, pp. 120-122). They might try to do a good job out of a sense of civic duty, but there is no pecuniary disincentive that deters them from believing that handsome defendants are less likely to be guilty, or that DNA evidence is unreliable. Jurors facing this incentive structure tend to consume a lot of irrational beliefs about the probability that a defendant is guilty.

Perhaps as a second-best solution, legal rules of evidence often explicitly recognize that jurors are not rational, and withhold evidence that juries are likely to process irrationally. Under current United States federal rules of evidence, judges weigh information's 'probative value' against its 'prejudicial effect', and keep it from the jury if the latter substantially outweighs the former. As one evidence text explains, this prejudicial effect consists in

'the injection of undue emotionalism into the proceeding arousing hostility, anger, or sympathy on the part of the jury',

or

'the likelihood that the jury will misuse the evidence in some way or give it undue weight' (Mueller and Kirkpatrick 1995, p. 197).

Even if judges decide not to bar prejudicial evidence, they often require measures to reduce its emotional impact: Courts may exclude a color photograph of a murder victim, but agree to admit a black and white version or an artist's sketch of the same picture. If jurors had rational expectations, it would be hard to explain why seeing graphic photos of the murder victim would provoke them to convict an innocent person, and even harder to understand why a color photo would have more impact than a black and white version.

Similarly, juries are rarely able to see evidence about a defendant's prior criminal record, the assumption being that juries would overweight its significance. As a famous Supreme Court ruling explains, prior criminal acts are inadmissible evidence 
'not because character is irrelevant; on the contrary, it is said to weigh too much with the jury and to so overpersuade them as to prejudge one with a bad general record' (Mueller and Kirkpatrick 1995, pp. 217-218; emphasis added).

Admitting such evidence might give authorities bad incentives, but rational jurors would respond by downweighting the importance of prior convictions (and rational citizens might in turn vote to increase sanctions for knowingly prosecuting innocent defendants with criminal records).

\section{THE OPTIMALITY OF IRRATIONALITY}

If people rationally select their level of irrationality, the standard conclusions about the optimality of unregulated private choice within one's budget set apply ${ }^{16}$. People choose to be irrational because the private costs of the belief are less than the private benefits. It is when the costs of irrationality spill over onto other people that efficiency problems arise. What welfare implications can be drawn for the previous examples?

\section{Inefficient Irrationality}

The externalities of irrational political belief are omnipresent. In an election, the private cost of irrationality is effectively zero, even though the aggregate impact may be large. It is cheap for an individual to irrationally underestimate the costs of war, but if enough people buy this opinion the result could be a disaster. Irrational views about the effects of tariffs, price controls, or expelling unpopular minorities would have similar but less drastic efficiency consequences.

The same applies to juries: Collectively, the opinions of juries are a primary determinant of the efficiency of the legal system. But individually, a juror can consume irrational beliefs about race, economics, or crime for free. It costs a jury nothing to disregard scientific evidence in their deliberations, or to buy into the expert testimony of a charlatan (Huber 1991).

Admittedly, under quite special circumstances, widespread individual irrationality cancels out (Caplan 2000 c). If irrationally biased voters on one side of

16. However, paternalistic regulations could conceivably reduce the price of irrationality. Paternalism could force an agent to take wealth-enhancing actions that conflict with his beliefs without actually abandoning those beliefs. On the other hand, there could be additional disutility of being forced to act against one's convictions. 
an issue exactly balance the irrationally biased voters on the other side, the median voter's expectations remain rational ${ }^{17}$. If one group irrationally over-estimates the benefits of complete free trade, while an equal sized group irrationally over-estimates the benefits of autarky, the aggregate electoral impact of irrationality is nil. But this auspicious coincidence is quite unlikely. There may be strong a priori reasons to think that the mean (and median) measurement error will be zero, but theory has nothing to say about mean or median preferences.

\section{Efficient Irrationality}

The inefficiently high level of political and juror irrationality may be contrasted to an essentially optimal level of religious and pseudo-scientific irrationality. Before the advent of religious toleration, religiously-inspired irrational opinions had large social costs from the suppression of scientific progress, inquisitions, and religious wars - and the same social costs continue today in countries where religious intolerance persists. At least in the Western democracies, the impact of irrationality is now largely internalized by believers, who, e.g., reject scientific evidence, abstain from medical treatment, constrain their career options, and so on, but cannot compel non-believers to do the same.

The scientific community has also greatly reduced the negative externalities of irrational belief. When astrologers and astronomers could deposit their findings in a common scientific pool, the irrationality of the astrologers dragged down the reputation of astronomers, diluting the latter's incentive to be rational. Scientists' self-segregation from the broader pseudo-scientific community realigned incentives, creating one sub-culture that rewards rationality and profits from its reputation for practical results, and another sub-culture that taxes rationality and profits from telling people what they want to hear. Intellectually separating these markets lets people consume pseudo-science without impairing scientific progress.

\section{CONCLUSION}

Economists were quick to apply economics to ignorance, but have often ignored irrationality, explained it away, or admitted it on an ad hoc basis. But as Muth noted in his original treatment of rational expectations,

17. Note further that not all elections are majoritarian. Many jury verdicts require unanimity; one stubbornly irrational person in favor of acquittal can hang the jury even if there is an equally stubbornly irrational person in favor of conviction. 
'Rationality is an assumption that can be modified. Systematic biases, incomplete or incorrect information, poor memory, etc., can be examined with analytical methods based on rationality' (1961, p. 330).

The strategy of this paper to acknowledge the existence of irrationality as nothing more than another economic good that actors have preferences over.

Analyzing irrationality with economic tools strongly suggests that the concept of rational ignorance has been oversold. Try to interpret Hoffer's political or religious true believer as an instance of rational ignorance:

\footnotetext{
'It is the true believer's ability to 'shut his eyes and stop his ears' to facts that do not deserve to be either seen or heard which is the source of his unequaled fortitude and constancy ... And it is the certitude of his infallible doctrine that renders the true believer impervious to the uncertainties, surprises, and unpleasant realities of the world around him' (1951, p. 76).
}

While there is a family resemblance, important pieces of the puzzle do not fit.

Diverse applications suggest themselves. This paper could only explore them in a cursory manner; more intensive explorations provide a fruitful outlet for future research. The ability of rational irrationality to provide sound microfoundations for the economic analysis of politics seems particularly promising. Political economy has reached an impasse: the theoretical case for the efficiency of political markets (Becker 1976a, Wittman 1989, 1995) seems impossible to reconcile with the empirical and intuitive case for political failure (e.g., Olson 1996, Shleifer 1998). Recognizing that political actors are not merely rationally ignorant but often rationally irrational may resolve the paradox (Caplan $2000 \mathrm{c}$, forthcoming).

The political scientist Gaetano Mosca laid down a powerful challenge to economics:

'Economic science has penetratingly investigated the laws that regulate the production and distribution of wealth. It has as yet done little with the relations of those laws to other laws that operate in the political organization of human societies. Economists have not concerned themselves with those beliefs, those collective illusions, which sometimes become general in given societies, and which form so large a part of the history of the world - as has been well said, man does not live by bread alone' (1923, p. 328).

While some economists argue that irrationality cannot be reconciled with the economic approach to human behavior (e.g., Becker 1976b, pp. 11-13), the application of the economic way of thinking to irrationality can also be seen as a striking vindication of economic imperialism. 


\section{RATIONAL IGNORANCE VERSUS RATIONAL IRRATIONALITY}

\section{REFERENCES}

Akerlof, George (1989). The Economics of Illusion, Economics and Politics. 1: 1-15.

Akerlof, George and William Dickens (1982). The Economic Consequences of Cognitive Dissonance, American Economic Review. 72: 307-319.

Akerlof, George and William Dickens (1984). The Economic Consequences of Cognitive Dissonance, in: George Akerlof, An Economic Theorist's Book of Tales. Cambridge: Cambridge University Press: $123-144$.

Arendt, Hannah (1973). The Origins of Totalitarianism. New York: Harcourt, Brace \& World Press.

Baumgarten, Bernd and Adrian Favell (eds.) (1995). New Xenophobia in Europe. London: Kluwer Law International.

Becker, Gary (1968). Crime and Punishment: An Economic Approach, Journal of Politic Economy. 76: $169-217$.

Becker, Gary (1976a). Toward a More General Theory of Regulation: Comment, Journal of Law and Economics. 19: 248-248.

Becker, Gary (1976b). The Economic Approach to Human Behavior, in: Gary Becker, The Economic Approach to Human Behavior. Chicago: University of Chicago Press: 3-14.

Becker, Gary (1976c). On the New Theory of Consumer Behavior, in: Gary Becker, The Economic Approach to Human Behavior. Chicago: University of Chicago Press: 131-149.

Becker, Gary (1983). A Theory of Competition Among Pressure Groups for Political Influence, Quarterly Journal of Economics. 98: 371-400.

Becker, Jasper (1996). Hungry Ghosts: Mao's Secret Famine. New York: The Free Press.

Bender, Bruce and John Lott (1996). Legislator Voting And Shirking: A Critical Review of the Literature, Public Choice. 87: 67-100.

Blais, Andre and Robert Young (1999). Why Do People Vote? An Experiment in Rationality, Public Choice. 99: 39-55.

Brennan, Geoffrey and Loren Lomasky (1989). Large Numbers, Small Costs: The Uneasy Foundations of Democratic Rule, in: Geoffrey Brennan and Loren Lomasky (eds.), Politics and Process: New Essays in Democratic Thought. Cambridge: Cambridge University Press: 42-59.

Brennan, Geoffrey and Loren Lomasky (1993). Democracy and Decision: The Pure Theory of Electoral Preference. Cambridge: Cambridge University Press.

Camerer, Colin (1995). Individual Decision Making, in: John Kagel and Alvin Roth (eds.), The Handbook of Experimental Economics. Princeton, NJ: Princeton University Press: 587-703.

Caplan, Bryan (2000a). Rational Irrationality: A Framework for the Neoclassical-Behavioral Debate, Eastern Economic Journal. 26: 191-211.

Caplan, Bryan (2000b). Systematically Biased Beliefs About Economics: Robust Evidence of Judgmental Anomalies from the Survey of Americans and Economists on the Economy, unpublished.

Caplan, Bryan (2000c). The Logic of Collective Belief, unpublished.

Caplan, Bryan (forthcoming). Rational Irrationality and the Microfoundations of Political Failure, Public Choice.

Coate, Stephen and Stephen Morris (1995). On the Form of Transfers to Special Interests, Journal of Political Economy. 103: 1210-1235.

Conquest, Robert (1985). Harvest of Sorrow: Soviet Collectivization and the Terror-Famine. New York: Oxford University Press.

Cowen, Tyler (1998). The Esteem Theory of Norms: Directions and Extensions, unpublished.

Downs, Anthony (1957). An Economic Theory of Democracy. New York: Harper.

Eichenberger, Reiner and Felix Oberholzer-Gee (1998). Rational Moralists: The Role of Fairness in Democratic Economic Politics, Public Choice. 94: 191-210.

Fremling, Gertrud and John Lott (1989). Time Dependent Information Costs, Price Controls, and Successive Government Intervention, Journal of Law, Economics and Organization. 5: 293-306.

Fremling, Gertrud and John Lott (1996). The Bias Towards Zero in Aggregate Perceptions: An Explanation Based on Rationally Calculating Individuals, Economic Inquiry. 34: 276-295. 


\section{BRYAN CAPLAN}

Frey, Bruno (1997). Rational Choice in Religion - and Beyond. Comment, Journal of Institutional and Theoretical Economics. 153: 279-284.

Frey, Bruno and Reiner Eichenberger (1991). Anomalies in Political Economy, Public Choice. 68: $71-89$.

Frey, Bruno and Reiner Eichenberger (1994). Economic Incentives Transform Psychological Anomalies, Journal of Economic Behavior and Organization. 17: 215-234.

Friedrich, Carl and Zbigniew Brzezinski (1965). Totalitarian Dictatorship and Autocracy. New York: Praeger Publishers.

General Social Survey (1996). URL http://www.icpsr.umich.edu/GSS/home.htm.

Grinspun, Ricardo and Maxwell Cameron (eds.) (1993). The Political Economy of North American Free Trade. London: Macmillan.

Haltiwanger, John and Michael Waldman (1989). Rational Expectations in the Aggregate, Economic Inquiry. 27: 619-636.

Hardin, Russell (1997). The Economics of Religious Belief, Journal of Institutional and Theoretical Economics. 153: 261-278.

Hoffer, Eric (1951). The True Believer: Thoughts on the Nature of Mass Movements. New York: Harper and Row.

Huber, Peter (1991). Galileo's Revenge: Junk Science in the Courtroom. New York: Basic Books.

Iannaccone, Laurence (1992). Sacrifice and Stigma: Reducing Free-riding in Cults, Communes, and Other Collectives, Journal of Political Economy. 100: 271-291.

Iannaccone, Laurence (1998). Introduction to the Economics of Religion, Journal of Economic Literature. 36: $1468-1495$.

Kirchgässner, Gebhard (1992). Towards a Theory of Low-Cost Decisions, European Journal of Political Economy. 8: 305-320.

Kirchgässner, Gebhard and Werner Pommerehne (1993). Low-Cost Decisions as a Challenge to Public Choice, Public Choice. 77: 107-115.

Kliemt, Hartmut (1986). The Veil of Insignificance, European Journal of Political Economy. 2: 333 344.

Kuran, Timur (1995a). Private Truths, Public Lies: The Social Consequences of Preference Falsification. Cambridge: Harvard University Press.

Kuran, Timur (1995b). Islamic Economics and the Islamic Subeconomy, Journal of Economic Perspectives. 9: 155-173.

Kuran, Timur and Cass Sunstein (1999). Availability Cascades and Risk Regulation, Stanford Law Review. 51: 683-768.

Locke, John (1951/1700). An Essay Concerning Human Understanding, Vol. 2. Fraser, Alexander, ed. New York: Dover Publications.

Magee, Stephen, William Brock, and Leslie Young (1989). Black Hole Tariffs and Endogenous Policy Theory: Political Economy in General Equilibrium. Cambridge: Cambridge University Press.

Montgomery, James (1996). Contemplations on the Economic Approach to Religious Behavior, American Economic Review Papers \& Proceedings. 86: 443-447.

Mosca, Gaetano (1939). The Ruling Class. New York: McGraw Hill.

Mueller, Christopher and Laird Kirkpatrick (1995). Evidence. Boston: Little, Brown, and Co.

Muth, John (1961). Rational Expectations and the Theory of Price Movements, Econometrica. 29: $315-335$.

Nisbett, Richard and Lee Ross (1980). Human Inference: Strategies and Shortcomings of Social Judgment. Englewood Cliffs, NJ: Prentice-Hall.

Olson, Mancur (1965). The Logic of Collective Action: Public Goods and the Theory of Groups. Cambridge: Harvard University Press.

Olson, Mancur (1982). The Rise and Decline of Nations: Economic Growth, Stagflation and Social Rigidities. New Haven: Yale University Press.

Olson, Mancur (1996). Big Bills Left on the Sidewalk: Why Some Nations are Rich and Others are Poor, Journal of Economic Perspectives. 10: 3-24.

Orwell, George (1983). Nineteen Eighty Four. New York: Signet Classic. 


\section{RATIONAL IGNORANCE VERSUS RATIONAL IRRATIONALITY}

Payne, Stanley (1995). A History of Fascism: 1914-1945. Madison, Wisconsin: University of Wisconsin Press.

Pesaran, M. Hashem (1987). The Limits to Rational Expectations. Oxford: Blackwell.

Rabin, Matthew (1998). Psychology and Economics, Journal of Economic Literature. 36: 11-46.

Randi, James (1989). Flim-Flam! Psychics, ESP, Unicorns, and Other Delusions. Buffalo, NY: Prometheus Books.

Reynolds, Vernon, Vincent Falger, and Ian Vine (1987). The Sociobiology of Ethnocentrism: Evolutionary Dimensions of Xenophobia, Discrimination, Racism and Nationalism. Athens, Georgia: University of Georgia Press.

Quattrone, George and Amos Tversky (1988). Contrasting Rational and Psychological Analysis of Political Choice, American Political Science Review. 82: 716-736.

Sagan, Carl (1995). The Demon-Haunted World: Science as a Candle in the Dark. New York: Random House.

Shleifer, Andrei (1998). State versus Private Ownership, Journal of Economic Perspectives. 12: 133150.

Sheffrin, Steven (1996). Rational Expectations. Cambridge: Cambridge University Press.

Schumpeter, Joseph (1976). Capitalism, Socialism, and Democracy. New York: Harper.

Survey of Americans and Economists on the Economy (1996). The Washington Post, October 16. Kaiser Family Foundation and Harvard University, \#1199.

Tönnesmann, Wolfgang (1987). Group Identification and Political Socialisation, in: Vernon Reynolds, Vincent Falger, and Ian Vine (eds.), The Sociobiology of Ethnocentrism: Evolutionary Dimensions of Xenophobia, Discrimination, Racism and Nationalism. Athens, Georgia: University of Georgia Press: 175-207.

Tullock, Gordon (1980). Trials on Trial: The Pure Theory of Legal Procedure. New York: Columbia University Press.

Watts, Meredith (1997). Xenophobia in United Germany. NY: St. Martin's Press.

Wintrobe, Ronald (1998). The Political Economy of Dictatorship. Cambridge: Cambridge University Press.

Wittman, Donald (1995). The Myth of Democratic Failure: Why Political Institutions are Efficient. Chicago: University of Chicago Press.

Wittman, Donald (1989). Why Democracies Produce Efficient Results, Journal of Political Economy. 97: $1395-1424$.

\section{SUMMARY}

The paper presents a model of 'rational irrationality' to explain why political and religious beliefs are marked not only by low information (as the notion of rational ignorance highlights), but also by systematic bias and high certainty. Being irrational - i.e., deviating from rational expectations - is modeled as a normal good. The reason that irrationality in politics and religion is so pronounced is that the private repercussions of error are virtually nonexistent. The consumption of irrationality can be efficient, but it will usually not be when the private and the social cost of irrationality differ - for example, in elections.

\section{ZUSAMMENFASSUNG}

Diese Studie entwickelt ein Modell 'rationaler Irrationalität', um zu erklären, warum politische und religiöse Weltvorstellungen nicht nur durch mangelnde Information beeinflusst sind (wie der Begriff der rationalen Ignoranz hervorhebt), sondern auch durch systematische Verzerrung und hochgradige Sicherheit. Irrational zu sein - d.h. die Abweichung von rationalen Erwartungen - ist modelliert als 


\section{BRYAN CAPLAN}

normales Gut. Der Grund, warum Irrationalität in Politik und Religion so hervorstechend sind, liegt darin, dass Fehler praktisch keine privaten Auswirkungen haben. Der Konsum von Irrationalität kann effizient sein, aber er ist es normalerweise dann nicht, wenn die privaten und sozialen Kosten der Irrationalität nicht identisch sind, wie zum Beispiel bei Wahlen.

\section{RÉSUMÉ}

Cet article présente un modèle 'd'irrationalité rationnelle' expliquant pourquoi les croyances politiques et religieuses se caractérisent non seulement par un faible niveau d'information (comme le souligne la notion d'ignorance rationnelle), et mais aussi par un biais systématique et par une forte certitude. Être irrationnel, i.e., dévier des anticipations rationnelles - est modélisé ici comme un bien normal. Puisque les répercussions privées de l'erreur en matière de croyances politiques et religieuses sont virtuellement inexistantes, l'irrationalité de ces croyances est si prononcée. La consommation d'irrationalité peut être efficace, mais ce ne sera habituellement pas le cas lorsque le coût privé et le coût social de l'irrationalité diffèrent - par exemple, pendant des élections. 